\title{
Serum and tear immunoglobulin levels in acute adenovirus conjunctivitis
}

\author{
A. K. GUPTA AND G. S. SARIN \\ From the Guru Nanak Eye Centre and Maulana Azad Medical College, New Delhi, India
}

\begin{abstract}
SUMmary Tear and serum IgG, IgA, and IgM levels were measured in 35 healthy subjects and 31 patients with acute conjunctivitis due to adenovirus 2,7 , and 8 infections. Serum IgG and IgM levels were found to be significantly low and there was no change in the serum $\operatorname{IgA}$ level. There was a significant rise in the tear IgG level. A progressive decline in the serum immunoglobulin level with the severity of the disease was observed. The changes in the immunoglobulin levels in serum and tears showed a tendency to reach normal levels with clinical improvement.
\end{abstract}

Many epidemics of acute viral conjunctivitis have been reported from Asia, Africa, and Europe during the past decade. ${ }^{1-10}$ However, no studies have been reported on the serum and tear immunoglobulin levels in the disease. The present study deals with observations on immunoglobulin levels in serum and tears in patients suffering from acute adenovirus conjunctivitis (acute and remission stages) which occurred in epidemic form during July-August 1981. The findings regarding adenovirus culture and serological titres have been described elsewhere. ${ }^{11}$

\section{Materials and methods}

The study was carried out among 35 healthy subjects and 31 virologically confirmed patients with acute adenovirus conjunctivitis attending the outpatient department of Guru Nanak Eye Centre, New Delhi. The control group comprised healthy subjects who had no evidence of ocular or systemic disease and attended the Eye Centre mainly for the purpose of refraction during the same period. In the control group there were 28 males and 7 females, with mean age $32 \cdot 1$ years, and the patients comprised 26 males and 5 females, with mean age $31 \cdot 1$ years. The diagnosis of acute adenovirus conjunctivitis was established by detailed clinical examination, including slit-lamp biomicroscopy, bacterial culture, and specific serological studies. The patients were subgrouped as mild, moderate, and severe according to the intensity of chemosis and congestion. Eighteen

Correspondence to Dr A. K. Gupta, VI/6, Maulana Azad Medical College Campus, Kotla Road, New Delhi-110002, India. cases were due to adenovirus type 8,5 to adenovirus type 7 , and 8 to adenovirus type 2 .

The tear samples were collected by the technique described earlier. ${ }^{12}$ The samples of tears and serum were stored at $-20^{\circ} \mathrm{C}$ until assayed. The samples were analysed for immunoglobulins by single radial immunodiffusion. ${ }^{13}$ Monospecific goat antisera against heavy-chain human $\operatorname{IgG}, \operatorname{IgA}$, and $\operatorname{IgM}$ and their respective reference standards were obtained from Meloy Laboratories, Virginia, USA. The reference standard of secretory IgA from human colostrum was used for the measurement of IgA level in tears. In 10 patients the samples were collected during the stage of remission when there was no clinical evidence of the disease.

\section{Results}

Serum IgG, IgA, and IgM levels in healthy subjects and in patients with acute adenovirus conjunctivitis are given in Table 1. It was observed that there was no significant change in the serum IgA level $(p>0 \cdot 40)$, while the serum levels of IgG $(p<0.001)$ and IgM $(p<0.02)$ fell significantly in comparison with the levels in healthy subjects.

Table 2 shows the serum IgA, IgG, and IgM levels in mild, moderate, and severe types of acute conjunctivitis. The serum IgA level did not show any change with severity of disease when compared with the level in the healthy subjects $(p>0 \cdot 80, p>0 \cdot 50$, and $p>0.20$ in mild, moderate, and severe types respectively). However, the serum IgM level showed a significant fall in moderate $(p<0.025)$ and severe 
Table 1 Serum immunoglobulins level in $\mathrm{mg} / \mathrm{dl}$ in normal controls and acute adenovirus conjunctivitis

\begin{tabular}{|c|c|c|c|c|c|c|}
\hline \multirow[t]{2}{*}{ Immunoglobulins } & \multicolumn{3}{|c|}{ Normal control } & \multicolumn{3}{|c|}{ Acute adenovirus conjunctivitis } \\
\hline & Mean & $S D$ & Range & Mean & $S D$ & Range \\
\hline $\operatorname{Ig} A$ & $187 \cdot 5$ & $91 \cdot 5$ & $50-475$ & $169 \cdot 5$ & $71 \cdot 1$ & $40-274$ \\
\hline IgG & $1428 \cdot 0$ & $390 \cdot 6$ & $890-2100$ & $1046 \cdot 0$ & $393 \cdot 2$ & $204-1770$ \\
\hline IgM & $137 \cdot 6$ & $60 \cdot 9$ & $50-225$ & $107 \cdot 0$ & $48 \cdot 2$ & $45-283$ \\
\hline
\end{tabular}

SI conversion: $\mathrm{mg} / \mathrm{dl} \times 10=\mathrm{mg} / \mathrm{l}$.

Table 2 Serum immunoglobulins levels in $\mathrm{mg} / \mathrm{dl}$ in mild, moderate, and severe types of acute adenovirus conjunctivitis

\begin{tabular}{lccccccc}
\hline Types & $\begin{array}{l}\text { No. of } \\
\text { patients }\end{array}$ & IgA & $S D$ & IgG & $S D$ & IgM & $S D$ \\
\hline Mild & 5 & $201 \cdot 3$ & $45 \cdot 4$ & $1084 \cdot 0$ & $428 \cdot 0$ & $142 \cdot 3$ & $97 \cdot 0$ \\
Moderate & 21 & $170 \cdot 4$ & $74 \cdot 2$ & $1042 \cdot 1$ & $374 \cdot 8$ & $106 \cdot 8$ & $33 \cdot 1$ \\
Severe & 5 & $133 \cdot 6$ & $71 \cdot 2$ & $873 \cdot 8$ & $483 \cdot 3$ & $68 \cdot 3$ & $25 \cdot 5$ \\
\hline
\end{tabular}

SI conversion: $\mathrm{mg} / \mathrm{dl} \times 10=\mathrm{mg} / \mathrm{l}$.

$(p<0.001)$ types of the disease, while its level in the mild type $(p>0.95)$ remained unaltered in comparison with the level in healthy subjects. The serum IgG level showed a significant fall in all types of the disease $(\mathrm{p}<0.05, \mathrm{p}<0.001$, and $\mathrm{p}<0.01$ in mild, moderate, and severe types respectively) in comparison with the levels in healthy subjects.

The tear IgA level in healthy subjects $(23.3 \mathrm{mg} / \mathrm{dl}$, SD 9.5) and in patients with acute adenovirus conjunctivitis $(21.2 \mathrm{mg} / \mathrm{dl}$, SD 12.3$)$ did not show any statistically significant difference $(p>0 \cdot 50)$. Similarly, the mean tear IgM level which was detectable in 13 patients with acute adenovirus conjunctivitis (3.5 $\mathrm{mg} / \mathrm{dl}$ ) did not differ significantly from the mean value in 5 healthy subjects $(1.8 \mathrm{mg} / \mathrm{dl})$. However, the tear IgG level showed a highly significant rise (mean level $23.5 \pm 8.7 \mathrm{mg} / \mathrm{dl}$ ) and was detectable in all the patients suffering from acute adenovirus conjunctivitis, while it was detectable only in 2 healthy subjects $(1.5 \mathrm{mg} / \mathrm{dl}$ and $2 \cdot 9 \mathrm{mg} / \mathrm{dl}$ ). (SI conversion: $\mathrm{mg} / \mathrm{dl} \times 10=\mathrm{mg} / \mathrm{l}$ ).

Table 3 shows the tear IgA and IgG levels in mild, moderate, and severe types of acute adenovirus conjunctivitis. Tear IgG levels were consistently high in comparison with the level in healthy subjects irrespective of the severity of the disease process.

Figs. 1 and 2 show the levels of IgG, IgA, and IgM in the tears and serum respectively in healthy subjects and patients with acute adenovirus conjunctivitis (acute stage and remission stages). It was observed that the tear IgG level, which was markedly raised during the acute stage of the disease, fell significantly during remission. Similarly, the serum IgG level, which was significantly low during the acute stage of the disease, returned almost to the normal level during remission. There was no appreciable change in other immunoglobulins in the tears and serum of patients suffering from acute adenovirus conjunctivitis.

\section{Discussion}

Several studies ${ }^{14-17}$ have been reported on the tear immunoglobulin level in normal subjects, but not much information is available on the tear immunoglobulin levels in acute viral conjunctivitis. Sen and Sarin ${ }^{18}$ have observed that tear IgA and IgG levels remained unaltered in acute bacterial conjunctivitis. Bluestone et al. ${ }^{19}$ studied some patients with miscellaneous eye diseases and found only the $\operatorname{IgA}$ level rising in the tears; IgG was detectable and occasionally quantifiable in the tears. Others ${ }^{20}$ have found that the tear IgA level remained remarkably constant despite the presence of disease and that the tear IgG level rose in such conditions. The tear IgG level has also been reported as rising in disease of the external eye, and it was suggested that its rise was due to the transudation of serum proteins into the tears. ${ }^{21}$ In the present study it was observed that in most of

Table 3 Tear IgG and IgA in $\mathrm{mg} / \mathrm{dl}$ in mild, moderate, and severe types of acute adenovirus conjunctivitis

\begin{tabular}{llllr}
\hline Types & $I g A$ & $S D$ & $I g G$ & \multicolumn{1}{c}{$S D$} \\
\hline Mild & $23 \cdot 6$ & $18 \cdot 9$ & $24 \cdot 1$ & $12 \cdot 8$ \\
Moderate & $19 \cdot 7$ & $11 \cdot 8$ & $23 \cdot 5$ & $8 \cdot 9$ \\
Severe & $21 \cdot 5$ & $10 \cdot 8$ & $21 \cdot 5$ & $10 \cdot 6$ \\
\hline
\end{tabular}

SI conversion: $\mathrm{mg} / \mathrm{dl} \times 10=\mathrm{mg} / \mathrm{l}$. 


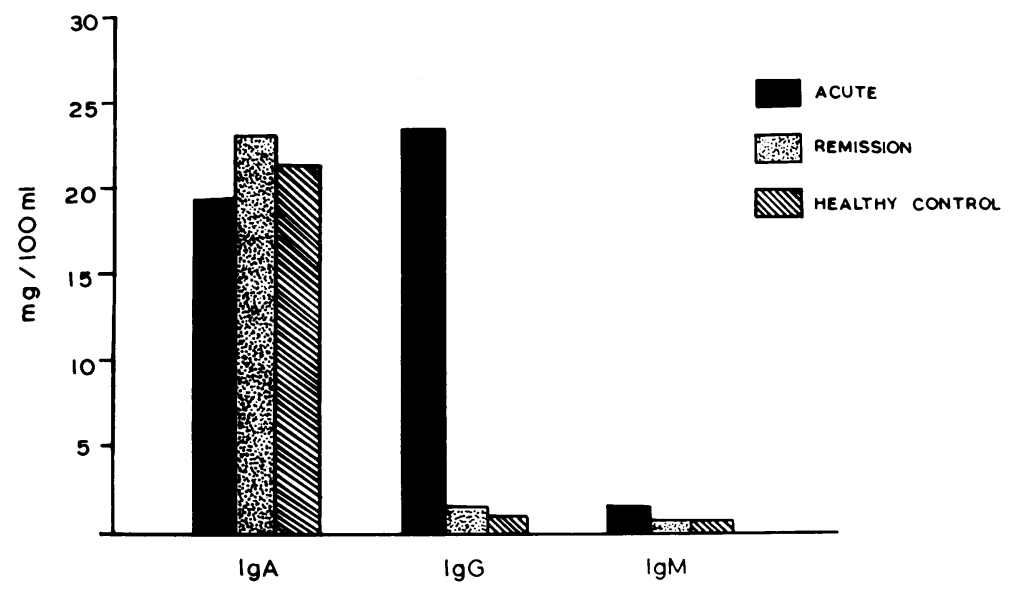

Fig. 1 Tear $\operatorname{Ig} G, \operatorname{Ig} A$, and $\operatorname{Ig} M$ in $\mathrm{mg} / \mathrm{dl}$ in healthy subjects and acute adenovirus conjunctivitis during acute and remission stages. (SI conversion: $m g / d l \times l 0=m g / l)$.

the patients with acute adenovirus conjunctivitis there was a substantial increase in the tear IgG level.

Our results agree with the findings of others ${ }^{21}$ that in inflammation of the eye, regardless of the cause, the tear IgG level rises and IgM may be detected. It is not clear whether the immunoglobulin levels of tears reflect local production, active transport from the blood, transudation from the serum, or some combination of these factors. ${ }^{21}$

Few studies are available on the serum immunoglobulin levels in viral infections. Kelkar et al. ${ }^{22}$ studied the serum immunoglobulin level in acute viral hepatitis and found significantly raised serum $\mathbf{I g G}$, IgA, and IgM levels. In another study, ${ }^{23}$ in VogtKoyanagi-Harada syndrome and pars planitis, no significant alteration in serum $\operatorname{IgG}, \operatorname{IgA}$, and $\operatorname{IgM}$ was found. In the present study no significant alteration was noted in the serum IgA level in acute adenovirus

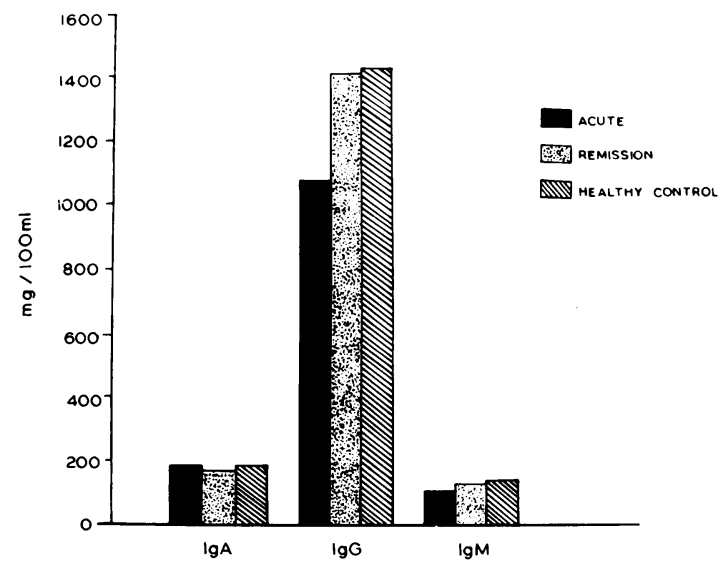

Fig. 2 Serum $\lg G, \lg A$, and $\lg M$ in $\mathrm{mg} / \mathrm{dl}$ in healthy subjects and acute adenovirus conjunctivitis during acute and remission stages. (SI conversion: $m g / d l \times 10=m g / l)$. conjunctivitis, while there was a significant fall in the serum IgG and IgM levels.

The reversal of immunoglobulin levels in tear and serum, as is evident from Figs. 1 and 2, is interesting, and it is obvious that immunoglobulin levels tend to attain the normal level as the disease recedes.

\section{References}

1 Diallo J, Castes M, Bassabi S. A prepos d'une conjunctivite haemorrhagique epidémique. Bull Soc Med Afr Noire Lang Fr 1971; 16: 73-5

2 Tullo AB. Higgins PG. An outbreak of adenovirus keratoconjunctivitis in Bristol. Br J Ophthalmol 1979; 63: 621-6.

3 Uchida $\mathrm{Y}$. Clinical aspects of acute haemorrhagic conjunctivitis in Tokyo. Clin Virol 1973; 1: 14-6.

4 Berg R. Ringstrom C. Wesslan T. Epidemic keratoconjunctivitis due to adenovirus type 8 in Uppsala (1966-67). Acta Pathol Microbiol Scand 1967; 187: (suppl): 5-9.

5 Gaudini OG, Omani M. Bouayed R. Isolation of enterovirus 70) during an outbreak of acute haemorrhagic conjunctivitis in Algeria in 1973. Arch Inst Pasteur Alger 1977; 52: 119-28.

6 Tan DSK, Yin Murphy M. Kandiah S. An outbreak of acute conjunctivitis caused by Coxsakie virus A 24 in Kuala Lumpur, Malayasia in 1978. Southeast Asian J Trop Med Public Health 1980; $11: 24-7$

7 Chatterjee S, Quarcoopome CO. Apenteng A. Unusual type of epidemic conjunctivitis in Ghana. $B r J$ Ophthalmol 1970; 54: 628-30.

8 Jones BR. Epidemic haemorrhagic conjunctivitis in London (1971). A conjunctival picornavirus infection. Trans Ophthalmol Soc UK 1972; 92: 625-7.

9 Grayston JT, Young Y, Johnson BP. Ko LS. Epidemic keratoconjunctivitis on Taiwan-etiological and clinical studies. Am J Trop Med 1964; 13: 492-3.

10 Parrott WF. An epidemic called Apollo. An outbreak of conjunctivitis in Nigeria. Practitioner 1971: 206: 253-5.

11 Gupta AK. Prasad AK. Epidemic acute conjunctivitis in Delhi (1981). A virological study. Afro-Asian J Ophthalmol 1982: 1: 62-5.

12 Sen DK, Sarin GS, Mani K. Saha K. Immunoglobulin in tears in normal Indian people. Br J Ophthalmol 1976; 60: 302-4.

13 Mancini G, Carbonara AO, Heremans JF. Immunochemical quantitation of antigens by radial immunodiffusion. Int $J$ Immunochem 1965; 2: 235-54. 
14 Barnett EV. Quantitation of immunoglobulins and L-chains by complement fixation tests. J Immunol 1968; 100: 1093-100.

15 Josephson AS, Weiner RS. Studies on the proteins of lacrimal secretion. J Immunol 1968; 100: 1080-92.

16 Little JM, Centifanto YM, Kaufman HE. Immunoglobulins in human tears. Am J Ophthalmol 1969; 68: 898-905.

17 Knopf HLS, Bertran DM, Kapikian AZ. Demonstration and characterization of antibody in tears following intranasal vaccination with inactivated type-13 rhinovirus. A preliminary report. Invest Ophthalmol Visual Sci 1970; 9: 727-34.

18 Sen DK. Sarin GS. Immunoglobulin concentration in human tears in ocular diseases. Br J Ophthalmol 1979; 63: 297-300.

19 Bluestone R, Easty DL, Goldberg LS, Jones BR, Petit TH. Lacrimal immunoglobulins and complement quantified by counter-immunoelectrophoresis. $\mathrm{Br} J$ Ophthalmol 1975; 59: 279-81.

20 Chandler JW, Leder R, Kaufman HE, Caldwell JR. Quantitative determination of complement component and immunoglobulins in tears and aqueous humour. Invest Ophthalmol Visual Sci 1974; 13: $151-3$.

21 McClellan BH, Whitney CR, Newman LP, Allansmith MR. Immunoglobulins in tears. Am J Ophthalmol 1973; 76: 89-101.

22 Kelkar SS, Warwadekar W, Dhunjibhoy K. Serum immunoglobulin G. M, and A in acute viral hepatitis. Indian J Med Res 1981; 73: 673-7.

23 Yokoyama MM, Matsui Y, Yamashiroya HM, et al. Humoral and cellular immunity studies in patients with Vogt-Koyanagi-Harada syndrome and pars plantis. Invest Ophthalmol Visual Sci 1981; 20: $364-70$. 